\section{SÔBRE DIREITOS DE VIZINHANÇA}

\section{Orlando da Cunha Carlos}

No conhecido e generalizado conceito, a propriedade é a relação jurídica, que vincula à nossa personalidade as coisas do mundo físico. Mas, as coisas do mundo físico aí se devem compreender apenas como ponto de incidência da relação de direito, já que esta se traduz empre numa vinculação universal entre um sujeito ativo determinado, e todos os outros sujeitos passivos, obrigados a respeitá-la, como agudamente observa FILADELFO DE AZEVEDO

$\mathrm{E}^{\prime} \cdot \mathrm{que}$, como direito subjetivo, a propriedade é um poder juri dico. $\mathrm{E}$ um poder jurídico só se concebe, se afirma e se revella em contraste com outros sujeitos de direito. Neste passo, há acôrdo pleno entre positivistas e jusnaturalistas.

Assim HAURIOU: " $E$ ' o equilíbrio dos dois poderes em presença, o individual e o social, que, por si mesmo, em virtude da ordem de coisas superior que êle realiza, o transforma em direitos da ordem de tempo, determina a sua medida. O êrro da maior parte dos individualistas foi o de crer que o direito individual podia se justificar ùnicamente pelo valor do indivíduo humano; um direito não nasce nunca de um princípio unilateral, não se realiza senão em um conjunto social e num equilíbrio prático".

Trata-se aí, como acentua J. DABIN, do direito jurídico, que pressupõe um conjunto social. Mas, mesmo no plano estritamente ético do direito moral, que se confunde com a idéia de justiça, exige-se o contraste de outrem. De resto, se existe um direito individual seja jurídico, ou seja moral, - é precisamente porque o indivíduo humano tem um certo valor. E o equilíbrio, de que fala HAURIOU, não pode, realmente, estabelecer-se senão entre dois valores.

$\mathrm{Se}$, no exemplo clássico, referido por DUGUIT, Robinson, na sua ilha, enquanto só, não tem direitos, 'e os adquire, Robinson, na contato com sêres humanos, não se segue, como pretende o mesmo autor, que, enquanto êle não faça parte de um conjunto socialmente
organizado, disponha sòmente de poderes de fato. Esses poderes de fato sofrem a censura da lei da moralidade, que osses poderes do agir de conformidade com o seu fim, e se transformam em relacöes de justiça, tão logo Robinson entre em contato com outro seme-
Ihante. Desde êsse momento, acrescenta J. DABIN, há "matéria" para justiça, como para tôdas as virtudes ad alterum (verdade, eqüidade, caridade...); desde êsse momento, Robinson está obrigado pelo dever de justiça para com seu alter ego, e êste tem o direito de usar da fôrça para repelir a agressão injusta.

Assim, conclui o autor citado, "o dever de justiça, com a exigibilidade que, moralmente, o caracteriza, não implica nenhuma vida social organizada, enquanto o direito jurídico, que é o direito da disciplina social, funda-se sôbre a hipótese de uma sociedade e de um Estado (sensu lato).

$\mathbb{E}^{\prime}$ assim a relação, como fato humano, como fenômeno de convivência, a gênese e a medida dos direitos.

Nasce do choque de duas personalidades conflitantes, e compóese na transação jurídica pacificadora.

Daí a impossibilidade de se formar relação jurídica entre coisas, porque o direito é fenômeno especificamente humano.

"A função dos bens, escreve FILADELFO AZEVEDO, - é, antes, de conteúdo do direito, formado entre seus donos, ou entre êstes, e terceiros".

E tão profunda é a personificação dêsse direito, que LUIGI STUURZO pôde escrever que "a propriedade é como uma participação da individualidade nas coisas". "As coisas tomam um nome e assumem para nós uma realidade relativa ao homem, no momento em que o homem as conhece, apropria-se delas, e delas se serve".

Direito subjetivo, como afetação de riquezas a necessidades individuais; função social, como querem os positivistas, correspondendo a uma afetação de riquezas a necessidades coletivas, conceituada como poder individual e dever social; situação de direito objetivo; ou situação jurídica subjetiva - de qualquer maneira que se conceitue, a propriedade há de sempre referir-se ao homem.

$\mathbb{E}$, como o homem é social, e social a sua vida, como fenômeno social, irredutivelmente, analisa-se a propriedade.

Assim, aprecie-se a propriedade em face de dois indivíduos isolados - Robinson e seu alter ego na ilha, ou em face do grupo politicamente organizado - Estado, no sentido geral -, e logo os limites e restrições de conteúdo se oferecerão a exame, como matéria do direito a definir, eis que a propriedade é um composto de conteúdo variável, conjunto de poderes e de direitos, reunião extremamente complexa de faculdades muito diversas pela sua natureza e pelo seu fím, e não direito simples, na lição de PIERRE DE HARVEN.

O princípio da limitação no interêsse geral ou social está no Direito Público, que o exprime na fórmula genérica do artigo 147 , da Constituição Federal: "O uso da propriedade será condicionado ao bem-estar social. A lei poderá, com observância do disposto no artigo $141, \S 16$, promover a justa distribuição da propriedade, com igual oportunidade para todos". 
Da que entende com os interêsses individuais, cura o Direito Privado, e só nos cabe examinar, no âmbito dêste estudo atinge a propriedade fundiária, por fôrça das relações de vizinhança

Neste capítulo, uma observação emerge e se impõe, ao primęiro exame: se é indubitável a impossibilidade de se formar a relação jurídica entre coisas, não é menos certo, como acentua FILADELFO AZEVEDO, que "o seu modo de ser e a dependência física, que podem ter, reciprocamente consideradas, hão de repercutir na formação e modificação do direito, afetando o poder do sujeito".

Assim os imóveis, continua o eminente jurista, "não podem ser concebidos isoladamente, mas sempre em relação com podem ser com os quais estão natural.e continuamente em contato" "A gularização da terra é obra arbitrária do homem, em face da continuidade do solo - só os móveis oferecem individualidade distinta no espaço".

A distinção e separação de fundos, escreve FERRINI, ainda que manifestada por sinais extrínsecos, como fossos, muros ou sebes, não consegue suprimir a sua natural relação de conexão e de recíproca dependência: "a própria natureza, portanto, de certo modo, impôslhes uma relação de mútua serventia e recíproca tolerância, que torna. incogitável a aplicação do princípio do isolamento de fato e de direito".

Já, portanto, o simples fato de contigüidade, oferece um primeiro elemento para o surto de limitações ao poder jurídico traduzido na propriedade fundiária.

Dessa contigüidade nasce um entrecruzamento de direitos opostos, que postulam conciliação: Direitos, que assentam em necessidades econômicas e morais, e que vão encontrar os seus justos limites nos critérios formulados pela política oportuna e pelo prudente govêrno. Limites não pròpriamente criados pelo direito, que nada mais faz do que registrá-los, aplicá-los, coordená-los e revesti-los de normas jurídicas, segundo a lição de COGLIOLO, que assim esclarece o asserto: "Examinem-se os limites postos por qualquer povo à propriedade, e resultará que cada um dêles se funda em razões estranhas. ao direito, mas, ao revêsso, derivantes de outras consideraçóes econômicas, agrícolas, estéticas, morais, e até de arbítrio de príncipes e de assembléias, ou de falazes esperanças de remediar males sociai com causas mais profundas do que o abuso individual da propriedade".

Esses limites, ajunta VINCENZO MICELLI, vão crescendo com o desenvolvimento da cooperação e da solidariedade social, e podem até determinar o modo por que aquêle poder deverá ser exercido na utilização da coisa.

Não há, dessarte, um critério fixo e invariável, para medir o conteúdo do direito de propriedade.

Os limites serão postos pelas necessidades da boa convivência,
A dificuldade da matéria tem torturado quantos a versaram.

Assim RUGGIERO: "Difícil é, porém, indicar um critério geral que, quanto às simples limitacões de vizinhanca em sentido restrito, nos conduza a um princípio único. E mais difícil ainda é procurar um princípio geral que, fora das limitações expressamente ditadas pela lei, determine os confins do domínio nas relações de vizinhança, sendo de grande importância teórica e prática investigá-lo, para resolver a grave e debatida questão de saber se, aos limites que a lei dita expressamente, outros se podem acrescentar".

Indaga, por sua vez, LODOVICO BARASSI: "Se é certo que há um dever de solidariedade, entre proprietários contíguos, até que ponto chega o dever de recíproca tolerância?"

Procurou-se, inicialmente, resolver o problema com a denominada teoria da imissão, fundada na máxima de ULPIANO, segundo a qual a cada um é lícito fazer na sua propriedade o que lhe agrade, desde que não se imiscua na propriedade alheia.

Observou-se, logo, que a solução era incompleta, porque, se é exato que a imissão na propriedade alheia pode, em regra, ser considerada como ato abusivo ou ilícito, não é menos verdadeiro que, por vêzes, as próprias imissões constituem casos de limites legais à propriedade.

Basta apontar o direito de escoamento natural de águas.

Por outro lado, o critério romanístico das imissões era muito restrito, pois nestas se compreendiam as invasões de corpos materiais, e por isso foi logo superado, admitindo-se, também, as imissões de imponderáveis, para conservar-se a velha técnica, e consistentes em rumores, exalações e comoções.

IHERING repeliu os dois conceitos, demonstrando que, se o critério das imissões corpóreas peca pela restrição, o das imissões de imponderáveis peca pelo excesso, podendo levar a soluções injustas. Propõe, em conseqüência, a substituição das imissões pela influência: E' vedado tudo o que possa influir sôbre o prédio vizinho.

Não há dúvida que influência é uma expressão demasiada vaga e indeterminada. Daí o desprestígio da tentativa de IHERING.

Surge, então BONFANTE, com um critério intermediário entre as imissões e a influência: $\mathrm{O}$ do facere in alieno, em contraposição ao facere in suo: Também com o facere, e não só com o immittere se lesa o direito alheio; isto é, não sòmente com o imitir substâncias no prédio alheio, mas também com a propagação de movimentos.

Até aqui, para empregar a terminologia de LODOVICO BARASSI, procurou-se a determinação qualitativa do dano a tolerar: imissões, influências ou facere.

Resta o problema da determinação quantitativa, do dano resul. tante e tolerável, da imissão, influência ou facere. 
IHERING formulou a teoria do uso normal da propriedade, permitidas as imissões quando resultantes do uso normal que o vizinho faça da coisa própria, e não impeçam ao proprietário o gôzo normal do seu prédio - como se lê no Código Civil Alemão.

Essa foi, também, a teoria acolhida no nosso Código Civil, como se vê do art. 554: O proprietário oú inquilino de um prédio tem o direito de impedir que o mau uso da propriedade vizinha possa prejudicar o sossêgo, a segurança e a saúde dos que o habitam.

Reputa FILADELFO AZEVEDO merecedores de caloroso aplauso os têrmos felizes em que foi vazada essa norma, tanto no estender a proteção aos ocupantes, como no colocar a prevenção ao lado da repressão. Lamenta, apenas, que se tenha empregado a expressão inquilino em lugar de habitante, que seria muito mais compreensiva.

À fórmula positiva - "uso normal", preferiu o nosso legislador a negativa - "mau uso".

Entretanto, nítida está aí a influência do direito germânico, no preceito inspirado por IHERING.

Ao espírito arguto de LODOVICO BARASSI não escapou, entretanto, a debilidade da fórmula em si. Daí a sua crítica: "Mas ainda permanece uma incerteza: onde termina o normal onde começa o injusto exercício da propriedade? Responde-se: a normalidade coincide com o que é consueto: uso normal é o uso habitual na região onde os prédios se encontram".

Objeta-se, então, que êsse conceito é perigoso, porque poderia impedir o progresso nos métodos de desfrutar a propriedade, desde que se afastasse do habitual, e ainda que se obtivesse maior vantagem social, à custa, embora, de um maior dano para os vizinhos.

BONFANTE, por sua vez, reputa ilógico o critério do uso normal, assim compreendido, e além de ilógico insidioso: Ilógico, porque pode chegar a impedir o aproveitamento mais natural das coisas, se superado aquêle limite; e além disso, um ato que constitua "uso normal" para a indústria, pode acarretar para o vizinho um incômodo intolerável, apesar de que não o seja para os outros.

Por êsse motivo, e reputando as imissões ou o facere sôbre o prédio vizinho como categorias sociais, não naturalísticas, considera-os proibidos sòmente quando as alterações danosas que sofra a propriedade, em conseqüência, repugnem à sensibilidade de um dado. ambiente social, e não sejam justificadas por uma geral e absoluta necessidade social.

Combinam-se, assim, o uso normal e a necessidade social.

Neste passo, podemos dizer que a evolução do nosso direito acompanhou o pensamento de BONFANTE, pois, ao critério do "mau uso", fixado no art. 554, do Código Civil, deve-se ajuntar o do "uso condicionado ao bem-estar social", postulado pelo art. 147 da Constituição Federal de 1946.

o Código Civil, preocupou-se mais com o indivíduo, pois se refere aos prejuízos, que venham a sofrer com o mau uso da propriedade vizinha, a segurança, o sossêgo e a saúde dos habitantes do prédio contíguo.

A Constituição Federal põe em relêvo o interêsse social.

Guias para o juiz serão êsses critérios, como ensina LODOVICO BARASSI, para o juiz, a cujo discernimento e fino senso ambiental, caberá a tarefa mais grave, de distingüir de lugar para lugar, e adaptar-se às exigências, à sensibilidade, aos usos locais, temperando os egoísmos com as superiores exigências sociais. 